\title{
Prevalence and parasitemia of Haemogregarina sp. in Podocnemis expansa (Testudines: Podocnemididae) from the Brazilian Amazon
}

\author{
Prevalência e parasitemia de Haemogregarina sp. em Podocnemis expansa \\ (Testudines: Podocnemididae) da Amazônia Brasileira
}

\author{
Amanda Maria Picelli ${ }^{1}$; Aluísio Vasconcelos de Carvalho ${ }^{1}$; Lúcio André Viana ${ }^{2 *}$; Adriana Malvasio ${ }^{3}$ \\ ${ }^{1}$ Programa de Pós-graduação em Ciências do Ambiente, Universidade Federal do Tocantins - UFT, Palmas, TO, Brasil \\ ${ }^{2}$ Laboratório de Parasitologia Veterinária, Centro de Ciências Biológicas e da Saúde, Universidade Federal de Mato Grosso do Sul - UFMS, \\ Campo Grande, MS, Brasil \\ ${ }^{3}$ Laboratório de Ecologia e Zoologia, Universidade Federal do Tocantins - UFT, Palmas, TO, Brasil
}

Received January 31, 2015

Accepted March 31, 2015

\begin{abstract}
Seventy-five turtles Podocnemis expansa in the Brazilian Amazon were examined for the presence of ectoparasites and hemoparasites. Samplings were performed in three study areas in the state of Tocantins, Brazil. Twenty-five specimens were sampled per study area (a commercial breeding facility, an indigenous subsistence breeding facility and a wild population of the Javaés River). Hemoparasites of the genus Haemogregarina were found in 66\% (50/75) of the turtle specimens, and the infections were restricted to the commercial breeding facility and to the wild population of the Javaés River. The mean level of parasitemia was 54/2,000 erythrocytes (2\%). There was no correlation between the body condition index of the chelonians and the level of parasitemia, with no significant difference between genders. No leeches were observed during the physical exams in any of the study areas, but the specimens from the commercial breeding facility were in poor physical condition with shell deformities and the presence of a relatively high amount of skin ulcerations, most likely caused by fungi and bacteria. This was the first study to record the occurrence of hemogregarines on a population scale in P. expansa and helps to increase knowledge about hemoparasites in chelonians in Brazil.
\end{abstract}

Keywords: Podocnemis expansa, prevalence, Haemogregarina, freshwater turtle.

\section{Resumo}

Setenta e cinco tartarugas Podocnemis expansa foram examinadas para a presença de ectoparasitos e hemoparasitos na região amazônica brasileira. As coletas foram realizadas no Estado do Tocantins, Brasil. No estudo foram amostrados 25 indivíduos por local, um criatório comercial, um criatório de subsistência indígena e uma população silvestre do rio Javaés. Foram encontrados hemoparasitos pertencentes ao gênero Haemogregarina em 66\% (50/75) dos animais, sendo que as infecçóes foram restritas ao criatório comercial e a população silvestre do rio Javaés. A parasitemia média foi de 54/2.000 eritrócitos (2\%). Não houve relação entre o índice de condiçáo corporal dos quelônios e os níveis de parasitemia e nem diferença quanto ao sexo dos animais. Não foram observadas sanguessugas durante os exames físicos, porém os animais do criatório comercial apresentaram condiçóes físicas ruins com deformidades no casco e presença de uma quantidade relativamente alta de ulceraçóes na pele, provavelmente causadas por fungos ou bactérias. Este estudo registrou a primeira ocorrência de hemogregarinas em uma escala populacional de $P$. expansa e contribui para expandir o conhecimento de hemoparasitos em quelônios no Brasil.

Palavras-chaves: Podocnemis expansa, prevalência, Haemogregarina, tartaruga de água doce.

\footnotetext{
*Corresponding author: Lúcio André Viana. Laboratório de Parasitologia

Veterinária, Centro de Ciências Biológicas e da Saúde, Universidade Federal do Mato Grosso do Sul - UFMS, Cidade Universitária, CP 549, CEP 79070-900, Campo Grande, MS, Brasil.

e-mail: lucviana74@gmail.com
} 


\section{Introduction}

Among the 35 chelonian species that occur in the Brazilian territory, Podocnemis expansa is the largest of the side-neck turtles, reaching a shell length up to $70 \mathrm{~cm}$ and a weight of $25 \mathrm{~kg}$ (VOGT, 2008). In Brazil, this freshwater turtle occurs in the Amazon Basin and Araguaia/Tocantins Basin and is popularly known as the Amazonian turtle (RUEDA-ALMONACID et al., 2007; VOGT, 2008). Podocnemis expansa has been a food resource for humans for a long time, and keeping this species in captivity as a meat source for subsistence and trade is an ancient practice among populations living along the rivers of the Amazon region (REBÊLO \& PEZZUTI, 2000). However, little is known about the appropriate management of $P$. expansa in captivity, and it is likely that the confinement of several animals may facilitate the dissemination and persistence of parasitism (TELFORD, 1971).

Hemoparasites of the Apicomplexa phylum, especially the hemogregarines (Apicomplexa: Adeleorina), are frequently found in reptiles (TELFORD, 2009). Parasites of the genus Haemogregarina are common in aquatic chelonians and have been recorded in several countries (TELFORD, 2009). These parasites are heteroxenic, and their transmission to aquatic chelonians is associated with leeches (DAVIES \& JOHNSTON, 2000; SIDDALL \& DESSER, 1992).

There are only two reports in the literature of the occurrence of hemogregarines in P. expansa: one report in the Peruvian Amazon (PINEDA-CATALAN et al., 2013) and another in
Northern Brazil (MUNDIM et al., 1994). In the current study, we assessed the prevalence and parasitemia of hemoparasites in wild $P$. expansa and in specimens kept in two captive facilities in the state of Tocantins, Brazil.

\section{Material and Methods}

\section{Study area}

The study was performed from October to December 2013 in three areas located in the Araguaia River Basin, state of Tocantins, Brazil (Figure 1). As the three study sites have different management processes to $P$. expansa are expected different parasitism levels. The first study area was located in the Javaés River (9'53'22.20"S, 50²'55.70”W), municipality of Pium, near the Araguaia National Park and north of Bananal Island. The area consists of preserved vegetation formed by typical fragments of Amazon forest and Cerrado (tropical savannah) vegetation. The second study area was a commercial breeding facility of $P$. expansa at the Praia Alta Ranch (1044’05.33”S, 4951'28.92”W), located in the municipality of Lagoa da Confusáo, at the banks of the Formoso River. This facility holds approximately 30,000 animals distributed in four tanks for growth and fattening. The third study area was a breeding facility in the Xambioá Indigenous Land $\left(7^{\circ} 05^{\prime} 10.09^{\prime \prime} \mathrm{S}, 49^{\circ} 11^{\prime} 02.99^{\prime \prime} \mathrm{W}\right)$ in the municipality of

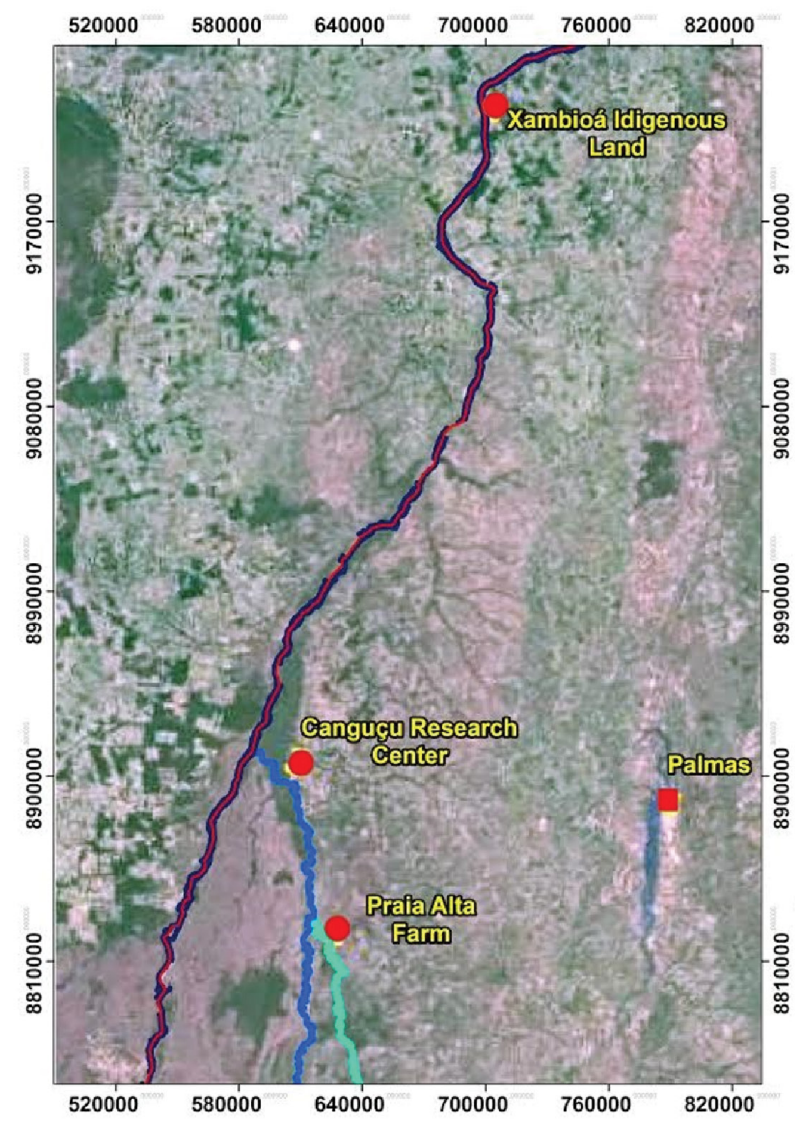

Figure 1. Map of state of Tocantins showing locations of study areas.

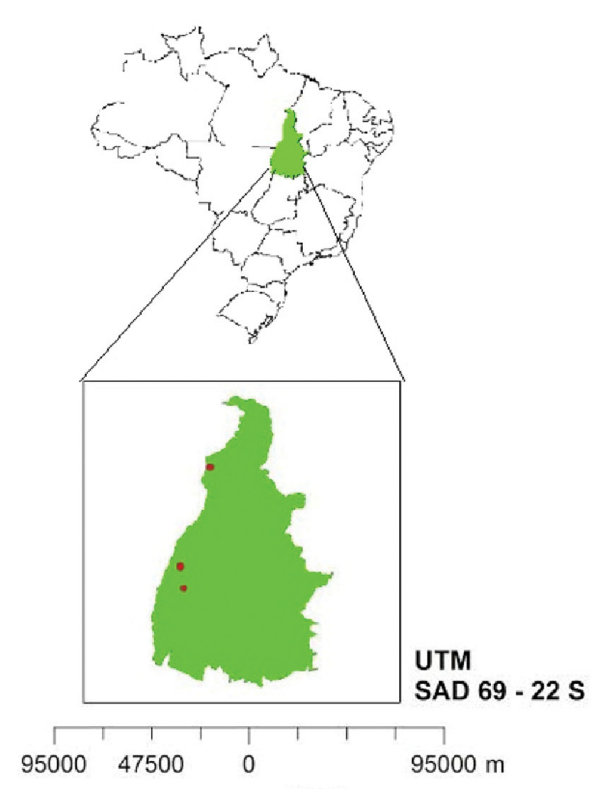

\section{Legend}
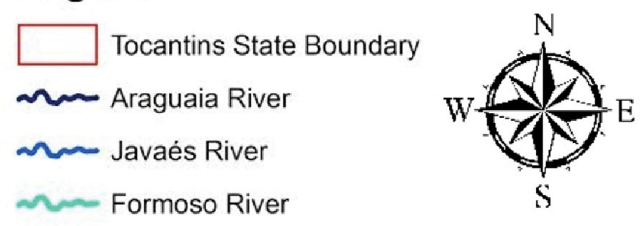
Santa Fé do Araguaia, an indigenous reservation located on the banks of the Araguaia River in the middle of the Amazon forest and inhabited by the Karajá indigenous people. That facility has only one tank with approximately 1,500 specimens of $P$. expansa.

\section{Animal and blood sampling}

To estimate the sample size was used an equation for a finite population (DANIEL \& CROSS, 2013), and data from a previous study were used to perform the calculation (ARMOND, 2008). In this study the prevalence was $99 \%$ of Haemogregarina sp., the size of the $P$. expansa wild population (N) was estimated at 2,100 individuals (Malvasio A, unpublished data), level of confidence $95 \%$, and standard error 5\%. Thus, the estimated sample size was 76 individuals of $P$. expansa. However, in the present study only 25 turtles were sampled in each of the three selected locations, totaling 75 animals. Considering the high prevalence rates in the study of Armond (2008), which sampled 80 individuals, we believe that our sample size represents the universe of the host population.

Samplings were restricted to animals with a carapace width between 15 and $60 \mathrm{~cm}$. In Brazil, this carapace width range is required for the slaughter of chelonians kept in captivity (BRASIL, 2008). In the Javaés River, wild animals were captured either by fishing with barbless fish hooks or by trawling (PORTELINHA et al., 2013) and were marked by drilling the tenth marginal scute of the carapace (MALVASIO et al., 2002). In the breeding facilities, chelonians were manually captured with the aid of a fishing hand net with a $40 \mathrm{~cm}$ diameter and $50 \mathrm{~cm}$ bag depth. The carapace width and weight of each captured specimen were measured, and then they were visually inspected for the presence of ectoparasites, such as leeches, and for possible infections.

Blood samples were collected by tail venipuncture, and then the chelonians were released back to their collection sites. Blood smears were fixed with absolute methanol and stained with 10\% Giemsa (EISEN \& SCHALL, 2000). The blood smears were examined for up to 20 minutes under a microscope $(400 \mathrm{x})$. The level of parasitemia was estimated by counting the parasite forms in 20 replicates of 100 erythrocytes (RBC) per field, totaling approximately 2,000 erythrocytes (GODFREY et al., 1987, 1990). This research was approved by IBAMA and the Brazilian Ministry of the Environment (approval number 38193-2/2013).

\section{Statistical analysis}

ANOVA was used to evaluate the differences in parasitemia among the animals collected in the different study areas. However, in the Xambioá Indigenous Land there was not positive animals, thus not entered in the analyzes. The correlation between parasitemia and body condition index (body weight in kilograms divided by the carapace width in $\mathrm{cm}$ ) was verified by a simple linear regression. The BioEstat 5.0 software (AYRES et al., 2007) was used for the statistical analysis. Values were considered statistically significant at $p<0.05$.

\section{Results}

Fractures in the shell and missing nails and phalanges were observed in the wild animals captured from the Javaés River, possibly caused by intraspecific aggression or predation. Both the wild animals and the specimens from the breeding facility of the Xambioá Indigenous Land appeared to be healthy and without visible anomalies. However, in the breeding facility of the Praia Alta Ranch, there were animals with soft shells and a relatively high amount of skin ulcerations, most likely caused by fungi and bacteria (ALEKSIĆ-KOVAČEVIĆ et al., 2014). The presence of unidentified slime material on the shells of the animals of the Praia Alta Ranch was also observed. No leeches were found on the chelonians in any of the study areas.

Hemoparasites of the genus Haemogregarina were recorded in $66 \%(50 / 75)$ of the chelonians, i.e., all individuals from the Javaés River and the breeding facility of the Praia Alta Ranch. The parasitic forms observed were meronts and intraerythrocytic gametocytes (Figure 2). The 25 specimens from the Xambioá Indigenous Land were not infected by hemoparasites.

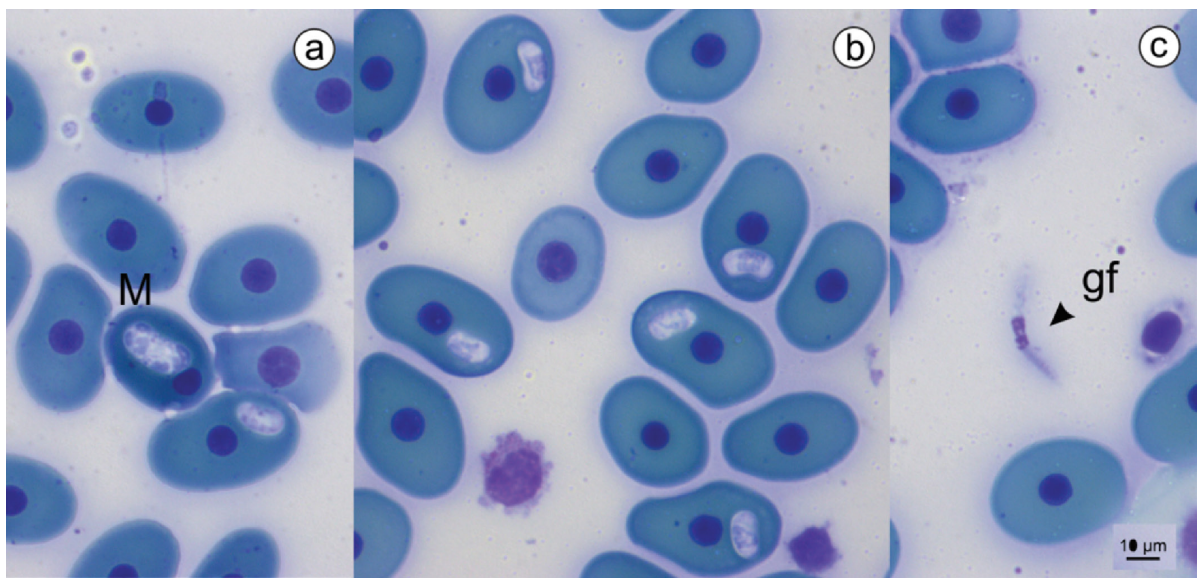

Figure 2. Parasitic forms of Haemogregarina sp. in Podocnemis expansa. (a) Meront (M) with six nuclei. (b) Gametocytes in erythrocytes. (c) Gamont free in blood (gf). Bar $=10 \mu \mathrm{m}$. 
The mean of parasitemia was 54/2,000 erythrocytes (3\% parasitized cells). There was a significant difference in the level of parasitemia between the specimens from the Javaés River and from the Praia Alta Ranch ( $F=14.7825 ; p \leq 0.001)$ (Table 1). There was no significant correlation between parasitemia and animals' body condition index $\left(R^{2}=0.0037 ; \mathrm{p}=0.28\right)$.

\section{Discussion}

\section{Physical examination}

The deformities and ulcerations observed in the animals of the Praia Alta Ranch were most likely related to management practices and to the tanks' infrastructure. In the Xambioá Indigenous Land, where the Amazonian turtles were healthy, the bottom and the sides of their only tank were coated with cement. The tank water came from the Araguaia River, and the tank was cleaned by changing the water every two days. However, there was no screen or filter in the water supply line to prevent the entry of leeches and microorganisms. Food was supplied every day and consisted of commercial fish food, various fruits, leaves from the riverbanks' trees, cassava and corn. In the breeding facility at the Praia Alta Ranch, where the animals were physically debilitated, the bottoms of the tanks were soil and only some sides were cemented. The diet consisted only of rice straw and crushed corn, supplied twice a day, every day. Cleaning was performed by changing the water every four days. Similar physical conditions to the ones observed in the P. expansa specimens kept in the Praia Alta Ranch were also observed in specimens of Dermatemys mawii in a study performed by Rangel-Mendoza et al., (2009). According to these authors, the $D$. mawii specimens were kept in captivity under inadequate management conditions, which led to relatively poor physical condition and lesions. Wild chelonians also examined in that study were healthy (RANGEL-MENDOZA et al., 2009).

\section{Prevalence}

This is the first report on the prevalence and parasitemia of Haemogregarina sp. in P. expansa chelonians on a population scale in Brazil (Table 2). The only previous records were in four animals collected in the Araguaia River, state of Goiás, Brazil (MUNDIM et al., 1994) and in 75 of 96 (78\%) specimens examined in Peru (PINEDA-CATALAN et al., 2013).

In the current study, all of the wild chelonians from the Javaés River and the chelonians from the breeding facility of the Praia Alta Ranch were infected by hemogregarines. It is important to highlight that the specimens kept at the Xambioá Indigenous Land and the Praia Alta Ranch were captured newly hatched from the wild and soon transferred to the captive facilities. Thus, they were not exposed to blood feeding by leeches in the wild. In addition, in both locations, the water in the tanks was obtained from nearby rivers and transported by pipes that did not have any physical barriers to prevent leech entry into the tanks. In the Xambioá Indigenous Land, the absence of chelonians infected by hemogregarines was most likely due to more efficient management of the animals in terms of cleaning and feeding, a lower density of animals in the tank or even an absence of leeches in the surrounding area. In the Xambioá Indigenous Land, there has been no report of leeches occurring in animals or in the breeding tank. In contrast, in the Praia Alta Ranch, the presence of leeches has been reported (ARMOND, 2008). In the latter location, the tanks' water is obtained from the Formoso River, and leeches may have entered the tanks in parasitized fishes or even with floating vegetation when they were not on their hosts (SAWYER, 1986).

The absence of vectors in wild chelonians of the Javaés River may be related to the period in which samplings were performed. Koffler et al. (1978) reported lower ectoparasitism by leeches during the summer months and during the reproductive period of Clemmys insculpta. In the region where the current study was performed, the climate, according to Köppen, is classified as tropical wet and dry (Aw), and summer is from November to April with $95 \%$ of the rainfall occurring during this period (FERREIRA \& CASTRO, 2003).

\section{Parasitemia}

The current study also recorded the second-highest parasitemia by hemogregarines in the Podocnemis genus and the highest parasitemia for the $P$. expansa species (Table 2). In $P$. unifilis of the Tapajós River, state of Pará, Brazil, the recorded level of parasitemia was $6 \%(\mathrm{n}=72)$ (SOARES et al., 2014). Until recently, the highest levels of parasitemia recorded were $1.7 \%(\mathrm{n}=7)$ in Chelydra serpentina (MCAULIFFE, 1977) and 1.6\% $(\mathrm{n}=45)$ in Testudo graeca ibera (MIHALCA et al., 2008).

Captive-bred reptiles under inadequate management, under confinement stress and with nutritional deficiencies are more susceptible to parasites (TELFORD, 1971; WILSON \& CARPENTER, 1996). Therefore, a higher prevalence and parasitemia of hemogregarines were expected in the animals kept in captivity. Although the prevalence levels were the same in the wild animals of the Javaés River and the specimens of the breeding facility of the Praia Alta Ranch, the mean level of parasitemia was significantly different in these locations, $4.2 \%$ vs. $1.2 \%$, respectively. This variation is most likely due to two aspects of the hemogregarines' transmission cycle in chelonians: leeches and the environment. It is likely that when conditions are amenable for the existence of leeches in the environment (wild or captive), infections by hemogregarines may occur continuously, maintaining high levels of parasitemia.

Studies have shown that the exposure of leeches to pesticides such as atrazine has negative effects on their growth, egg production,

Table 1. Descriptive analysis of Haemogregarina sp. in Podocnemis expansa in the state of Tocantins, Brazil.

\begin{tabular}{cccccc}
\hline Site & Mean parasitemia & $\mathbf{( \% )}$ & SD & Maximum (\%) & Minimum (\%) \\
\hline Javaés River & 84.16 & 4.2 & \pm 77.3 & 15.0 & 0.35 \\
Praia Alta Ranch & 24.12 & 1.2 & \pm 10.3 & 2.1 & 0.40 \\
Total & 54.14 & 2.7 & \pm 62.4 & 15.0 & 0.35 \\
\hline
\end{tabular}


Table 2. Prevalence and parasitemia of turtles Haemogregarina spp.

\begin{tabular}{|c|c|c|c|c|c|}
\hline Turtle species & Prevalence $\%$ & $\mathbf{N}$ & Parasitemia \% & Local & Reference \\
\hline Chelydra serpentina & 100 & 59 & 0.70 & Canada/Ontario & Siddall \& Desser, 1992 \\
\hline Chelodina oblonga & 100 & 13 & 0.38 & Australia & Scheelings \& Rafferty, 2012 \\
\hline Chelydra serpentina & 100 & 7 & 1.77 & EUA/Nebraska & McAuliffe, 1977 \\
\hline Chrysemys scripta elegans & 100 & 25 & 0.50 & Canada/Ontario & McAllister \& King, 1980 \\
\hline Emys orbicularis & 100 & 18 & 0.81 & Romenia/Drăgăşani & Mihalca et al., 2008 \\
\hline Emys orbicularis & 100 & 8 & 0.74 & Romenia/Drăgăşani & Mihalca et al., 2002 \\
\hline Kinosternon leucostumum & 100 & 8 & 0.05 & Costa Rica/Selva Verde & Rossow et al., 2013 \\
\hline Kinosternon scorpioides & 100 & 1 & 0.01 & Costa Rica/Selva Verde & Rossow et al., 2013 \\
\hline Rhinoclemmys funerea & 100 & 25 & 0.34 & Costa Rica/Selva Verde & Rossow et al., 2013 \\
\hline Podocnemis unifilis* & 98 & 72 & 6.00 & Brazil/Tapajós & Soares et al., 2014 \\
\hline Lissemys punctata andersoni & 93 & 15 & 0.91 & India/Western Bengala & Molla et al., 2013 \\
\hline Sternotherus oderatus & 89 & 9 & 0.34 & EUA/Georgia & Davis \& Sterrett, 2011 \\
\hline Testudo graeca ibera & 84 & 45 & 1.60 & Romenia/Greci & Mihalca et al., 2008 \\
\hline Podocnemis expansa & 78 & 96 & Not inf. & Peru & Pineda-Catalan et al., 2013 \\
\hline Clemmys insculpta & 75 & 20 & $<0.1$ & Canada/Ontario & Siddall \& Desser, 1992 \\
\hline Podocnemis sextuberculata & 75 & 27 & Not inf. & Peru & Pineda-Catalan et al., 2013 \\
\hline Podocnemis unifilis & 74 & 136 & Not inf. & Peru & Pineda-Catalan et al., 2013 \\
\hline Podocnemis expansa* & 66 & 75 & 2.70 & Brazil/Tocantins & This study \\
\hline Geoclemys hamiltonii & 60 & 10 & 0.39 & India/Western Bengala & Molla et al., 2013 \\
\hline Chelodina longicollis & 50 & 8 & 0.06 & Australia & Scheelings \& Rafferty, 2012 \\
\hline Dermatemys mawii & 43 & 51 & 1.40 & Mexico/Tabasco & Rangel-Mendoza et al., 2009 \\
\hline Chrysemys picta marginata & 41 & 70 & $<0.1$ & Canada/Ontário & Siddall \& Desser, 1992 \\
\hline Trachemys scripta & 40 & 5 & 0.06 & EUA/Georgia & Davis \& Sterrett, 2011 \\
\hline Phrynops geoffroanus* & 28 & 58 & Not inf. & Brasil/Uberlândia & Campos Brites \& Rantin, 2003 \\
\hline Chrysemys picta & 22 & 9 & 0.01 & EUA/Georgia & Davis \& Sterrett, 2011 \\
\hline Chrysemys picta bellii & Not inf. & 46 & 0.11 & EUA/Nebraska & McAuliffe, 1977 \\
\hline Emys blandingii & Not inf. & 15 & 0.25 & EUA/Nebraska & McAuliffe, 1977 \\
\hline Lissemys punctata punctata & Not inf. & 3 & Not inf. & India/Western Bengala & Ray \& Bhattacharjee, 1984 \\
\hline
\end{tabular}

feed intake and survival rate (STREIT \& PETER, 1978). In the tanks of the Praia Alta Ranch, the leeches are most likely exposed to environmental pressure from pesticides because the Formoso River that supplies the tanks traverses large tracts of agricultural areas with soybean, corn and rice crops. Therefore, the presence of pesticides could affect the leech population, leading to a decrease in the reinfection and parasitemia levels of the chelonians.

In a study of the parasitism of Geoffroy's side-necked turtle, Phrynops geoffroanus, by hemogregarines and leeches, Campos Brites \& Rantin (2004) recorded a prevalence of hemogregarines of $15.4 \%(n=26)$ in an agricultural area and $37.5 \%(n=32)$ in an urban area. Leeches were found only in the urban area. According to Campos Brites \& Rantin (2004), this variation is most likely related to the water quality of the Uberabinha River. Although there were pesticide residues in both sampled locations, the concentration of atrazine was 18 times higher in the rural area and was suggested as the main cause of the absence of leeches in the rural area.

The observed lack of a relationship between $P$. expansa body condition index and parasitemia suggests that parasites do not adversely affect the health of chelonians. Similarly, Rossow et al. (2013) did not find a significant correlation between parasitemia and body condition index in the aquatic chelonians Rhinoclemmys funerea, Kinosternon leucostumum and K. scorpioides from Costa Rica. However, hemogregarines can be harmful to their hosts when associated with other diseases despite the fact that they are not considered pathogenic (OPPLIGER et al., 1996; PEIRCE \& ADLARD, 2004). In wild snakes with high levels of Hepatozoon sp. parasitemia, decreases in the growth, body condition and survival of juveniles were observed. In these reptiles, low parasitemia levels were only observed in animals of advanced age (MADSEN et al., 2005; UJVARI \& MADSEN, 2005).

Amazonian chelonian ranching aims to prevent hunting and illegal meat trade. For the Praia Alta Ranch, it is necessary to change the tanks' infrastructure and management protocol to achieve more efficient and reliable production. The current study reported the occurrence of hemogregarines at the population scale of its host, the side-necked turtle P. expansa, and contributed to expanding the knowledge about hemoparasites in chelonians in Brazil.

\section{Acknowledgements}

Thank to the Coordenação de Aperfeiçoamento de Pessoal de Nível Superior (CAPES) for master scholarship to A. Picelli. We thank also to Conselho Nacional de Desenvolvimento Cientifico e Tecnologico (CNPq) for financial support to A. Malvasio (process no 552548/2011-1). 


\section{References}

Aleksić-Kovačević S, Özvegy J, Krstić N, Rusvai M, Jakab C, Stanimirović $\mathrm{Z}$, et al. Skin and skeletal system lesions of european pond turtles (Emys orbicularis) from natural habitats. Acta Vet Hung 2014; 62(2): 180-193. http://dx.doi.org/10.1556/AVet.2013.060. PMid:24334084.

Armond FN. Aspectos alimentares e do parasitismo em Podocnemis expansa de ambiente natural e criatório comercial no Estado do Tocantins [Dissertação]. Palmas: Universidade Federal do Tocantins; 2008.

Ayres M, Ayres M Jr, Ayres DL, Santos AA. Bioestat-aplicaçôes estatísticas nas áreas das ciências biomédicas. Belém: ONG Mamirauá; 2007.

Brasil. Ministério do Meio Ambiente - MMA. Instituto Brasileiro do Meio Ambiente e dos Recursos Naturais Renováveis - IBAMA. Instrução Normativa no 169 de 20 de fevereiro de 2008. Normatiza e institui as categorias de uso e manejo da fauna silvestre em cativeiro em território brasileiro [online]. Brasília: Diário Oficial da União; 2008. [cited 2014 Dec 15]. Available from: http://www.ibama.gov.br/category/1 ?download=66:169-2008

Campos Brites VL, Rantin FT. The influence of agricultural and urban contamination on leech infestation of freshwater turtles, Phrynops geoffroanus, taken from two areas of the Uberabinha River. Environ Monit Assess 2004; 96(1-3): 273-281. http://dx.doi.org/10.1023/ B:EMAS.0000031733.98410.3c. PMid:15327164.

Daniel WW, Cross CL. Biostatistics: a foundation for analysis in the health sciences. 10th ed. New York: John Wiley \& Sons; 2013.

Davies AJ, Johnston MRL. The biology of some intraerythrocytic parasites of fishes, amphibia and reptiles. Adv Parasitol 2000; 45: 1-107. PMid:10751939.

Davis AK, Sterrett S. Prevalence of haemogregarine parasites in three freshwater turtle species in a population in northeast Georgia, USA. Int J Zool Res 2011; 7(2): 156-163. http://dx.doi.org/10.3923/ijzr.2011.156.163.

Eisen RJ, Schall JJ. Life history of a malaria parasite (Plasmodium mexicanum): independent traits and basis for variation. Proc Biol Sci 2000; 267(1445): 793-799. http://dx.doi.org/10.1098/rspb.2000.1073. PMid:10819149.

Ferreira PD Jr, Castro PTA. Geological control of Podocnemis expansa and Podocnemis unifilis nesting areas in the Rio Javaés, Bananal Island, Brazil. Acta Amazon 2003; 33(3): 445-468. http://dx.doi.org/10.1590/ S0044-59672003000300010.

Godfrey RD Jr, Fedynich AM, Pence DB. Quantification of hematozoa in blood smears. J Wildl Dis 1987; 23(4): 558-565. http://dx.doi. org/10.7589/0090-3558-23.4.558. PMid:3119870.

Godfrey RD Jr, Pence DB, Fedynich AM. Effects of host and spatial factors on a haemoproteid community in mourning doves from western Texas. JWildl Dis 1990; 26(4): 435-441. http://dx.doi.org/10.7589/00903558-26.4.435. PMid:2250318.

Koffler BR, Seigel RA, Mendonça MT. The seasonal occurrence of leeches on the wood turtle, Clemmys insculpta (Reptilia, Testudines, Emydidae). J Herpetol 1978; 12(4): 571-572. http://dx.doi.org/10.2307/1563364.

Madsen T, Ujvari B, Olsson M. Old pythons stay fit; effects of haematozoan infections on life history traits of a large tropical predator. Oecologia 2005; 142(3): 407-412. http://dx.doi.org/10.1007/s00442-004-1742-9. PMid:15517406.

Malvasio A, Souza AM, Gomes N, Sampaio FAA, Molina FB. Variaçôes ontogenéticas na morfometria e morfologia do canal alimentar pósfaríngeo de Trachemys dorbignyi (Duméril \& Bibron, 1835), Podocnemis expansa (Schweigger, 1812), P. unifilis (Troschel, 1848) e P. sexturberculata (Cornalia, 1849) (Anapsida; Testudines). Publ Avulsas Inst Pau Bras His Nat 2002; 5: 39-51.

McAllister CT, King AW. Hemogregarines in the red-eared slider, Chrysemys scripta elegans (Wied) from Arkansas. Proc Ark Acad Sci 1980; 34: 124.

McAuliffe JR. An hypothesis explaining variations of hemogregarine parasitemia in different acquatic turtle species. J Parasitol 1977; 63(3): 580-581. http://dx.doi.org/10.2307/3280024. PMid:405469.

Mihalca AD, Achelaritei D, Popescu P. Haemoparasites of the genus Haemogregarina in a population of european pond turtles (Emys orbicularis) from Drăgăşani, Vâlcea county, Romania. Sci Parasitol 2002; 2: 22-27.

Mihalca AD, Racka K, Gherman C, Ionescu DT. Prevalence and intensity of blood apicomplexan infections in reptiles from Romania. Parasitol Res 2008; 102(5): 1081-1083. http://dx.doi.org/10.1007/s00436-0080912-9. PMid:18283494.

Molla SH, Bandyopadhyay PK, Gürelli G. On the occurrence of a Haemogregarinae (Apicomplexa) parasite from freshwater turtles of South 24 Parganas, West Bengal, India. Turkiye Parazitol Derg 2013; 37(2): 118-122. http://dx.doi.org/10.5152/tpd.2013.27. PMid:23955910.

Mundim AV, Mundim MJS, Santos ALQ. Ocorrência de hemoparasitas em tartaruga da Amazônia (Podocnemis expansa) (Testudinata: Pelomedusidae). Rev Centro Cienc Biomed Univ Fed Uberlandia 1994; 10(1): 111-113.

Oppliger A, Célérier ML, Clobert J. Physiological and behaviour changes in common lizards parasitized by haemogregarines. Parasitology 1996; 113(5): 433-438. http://dx.doi.org/10.1017/S003118200008149X.

Peirce MA, Adlard RD. Haemoparasites from clinical screening of reptiles in south-east Queensland, Australia. Vet Rec 2004; 155(22): 708-709. http://dx.doi.org/10.1136/vr.155.22.708. PMid:15605539.

Pineda-Catalan O, Perkins SL, Peirce MA, Engstrand R, Garcia-Davila C, Pinedo-Vasquez M, et al. Revision of hemoproteid genera and description and redescription of two species of chelonian hemoproteid parasites. $J$ Parasitol 2013; 99(6): 1089-1098. http://dx.doi.org/10.1645/13-296.1. PMid:24032642.

Portelinha TCG, Malvasio A, Piña CI, Bertoluci JA. Reproductive Allometry of Podocnemis expansa (Testudines: Podocnemididae) in Southern Brazilian Amazon. J Herpetol 2013; 47(2): 232-236. http:// dx.doi.org/10.1670/11-288.

Rangel-Mendoza J, Weber M, Zenteno-Ruiz CE, López-Luna MA, BarbaMacías E. Hematology and serum biochemistry comparison in wild and captive Central American river turtles (Dermatemys mawii) in Tabasco, Mexico. Res Vet Sci 2009; 87(2): 313-318. http://dx.doi.org/10.1016/j. rvsc.2009.03.006. PMid:19380155.

Ray R, Bhattacharjee A. Haemogregarina choudhuryi sp. n. (Apicomplexa: Haemogregarinidae) in common pond water turtle, Lissemys punctata punctata (Bonnaterre) from West Bengal. Acta Protozool 1984; 23: 67-74.

Rebêlo G, Pezzuti J. Percepçóes sobre o consumo de quelônios na Amazônia: sustentabilidade e alternativas ao manejo atual. Ambiente Soc 2000; (6-7) 85-104. http://dx.doi.org/10.1590/S1414-753X2000000100005.

Rossow JA, Hernandez SM, Sumner SM, Altman BR, Crider CG, Gammage $\mathrm{MB}$, et al. Haemogregarine infections of three species of aquatic freshwater turtles from two sites in Costa Rica. Int J Parasitol Parasites Wildl2013; 2: 131-135. http://dx.doi.org/10.1016/j.ijppaw.2013.02.003. PMid:24533326.

Rueda-Almonacid JV, Carr JL, Mittermeier RA, Rodríguez-Mahecha JV, Mast RB, Vogt RC, et al. Las tortugas y los cocodrilianos de los países andinos 
del trópicos. Bogotá: Editorial Panamericana; Conservación Internacional; 2007. no.6. Série de guías tropicales de campo.

Sawyer RT. Leech biology and behaviour. Oxford: Clarendon Press; 1986. vol. 1. Anatomy, Physiology, and Behaviour.

Scheelings TF, Rafferty AR. Hematologic and serum biochemical values of gravid freshwater Australian Chelonians. JWildl Dis 2012; 48(2): 314321. http://dx.doi.org/10.7589/0090-3558-48.2.314. PMid:22493107.

Siddall ME, Desser SS. Prevalence and intensity of Haemogregarina balli (Apicomplexa: Adeleina: Haemogregarinidae) in three turtle species from Ontario, with observations on intraerythrocytic development. Can J Zool 1992; 70(1): 123-128. http://dx.doi.org/10.1139/z92-018.

Soares P, de Brito ES, Paiva F, Pavan D, Viana LA. Haemogregarina spp. in a wild population from Podocnemis unifilis Troschel, 1848 in the Brazilian Amazonia. Parasitol Res 2014; 113(12): 4499-4503. http:// dx.doi.org/10.1007/s00436-014-4139-7. PMid:25284256.
Streit B, Peter HM. Long-term effects of atrazine to selected freshwater invertebrates. Arch Hydrobiol Suppl 1978; 55(1): 62-77.

Telford SR Jr. Hemoparasites of the reptilia: color atlas and text. Boca Raton: CRC Press; 2009.

Telford SR Jr. Parasitic diseases of reptiles. J Am Vet Med Assoc 1971; 159(11): 1644-1652. PMid:5005187.

Ujvari B, Madsen M. Age, parasites, and condition affect humoral immune response in tropical pythons. Behav Ecol 2005; 17(1): 20-24. http://dx.doi.org/10.1093/beheco/ari091.

Vogt RC. Tartarugas da Amazônia. Manaus: Editora INPA; 2008.

Wilson SC, Carpenter JW. Endoparasitic Diseases of Reptiles. Semin Avian Exot Pet 1996; 5(2): 64-74. http://dx.doi.org/10.1016/S1055937X(96)80019-3. 